Article

\title{
Monitoring of the PAL Enzymatic Activity and Polyphenolic Compounds in Leaves and Fruits of Two Myrtle Cultivars during Maturation
}

\author{
Silvia Medda ${ }^{(D)}$, Leonarda Dessena and Maurizio Mulas *(D) \\ Department of Agriculture, University of Sassari (Italy), Via De Nicola 9, 07100 Sassari, Italy; \\ silvia.medda@hotmail.it (S.M.); lalladessena@yahoo.it (L.D.) \\ * Correspondence: mmulas@uniss.it; Tel.: +39-079-229-334
}

Received: 11 August 2020; Accepted: 1 September 2020; Published: 3 September 2020

\begin{abstract}
The leaves and berries of myrtle (Myrtus communis L.) are rich in phenolic compounds, such as phenolic acids, flavonoids, and flavanols. The richness of these antioxidant compounds allows the potential use of myrtle biomasses as raw materials for medicinal and functional food products. Most of the phenolic compounds originate from the phenylpropanoid pathway, where phenylalanine ammonia lyase (PAL) enzyme activates the first step. The objective of this research is to study the activity of PAL as related to accumulation in the myrtle fruits and leaves of some phenolic compounds in the period between blossom and full berry ripening. With this aim, we compared two model genotypes with different fruit coloration. In leaves and berries of two cultivars, 'Giovanna' with pigmented berries and 'Grazia' with white berries, the PAL activity and content of polyphenols, anthocyanins, flavonoids, and tannins were determined with spectrophotometric methods. PAL activity was quite constant in leaves and variable in berries: Greater in berries of 'Giovanna' than in those of 'Grazia' cultivar, and increasing from berry color-break to full ripening. In berries, a positive correlation between PAL and flavonoids $(r=0.44)$, and between PAL and anthocyanins $(r=0.69)$, as well as a negative correlation between PAL and total polyphenols $(\mathrm{r}=-0.471)$, were found.
\end{abstract}

Keywords: phenylalanine ammonia lyase; myrtle leaves; myrtle berries; chemical analyses; phenolic compounds; phenylpropanoids

\section{Introduction}

The myrtle (Myrtus communis L.) is a medicinal and aromatic plant typical of the Mediterranean flora. It is a shrub, up to $5 \mathrm{~m}$ tall, characterized by intense green leaves rich in aromatic glands and white or pink flowers with aromatic glands, too, in the sepals. The fruits, based on color at ripening, are black-red or yellow-white berries, rich in little seeds [1,2].

Since ancient times, the plant use was for medical purposes, for example, in the care of cystitis and as a sedative for the stomach. Moreover, people used myrtle as a flavor enhancer in meat and sausages [1]. Nowadays, myrtle plant appreciation is in pharmacological, food, and cosmetic fields, and many studies have focused on the pharmacological properties of different parts of myrtle [3-7].

In Sardinia (Italy), the main use is the production of myrtle sweet liqueurs, known at the international level, and obtained from the hydroalcoholic infusions of berries and leaves (red myrtle and white myrtle, respectively).

Previous research focused on phenolic compounds present in myrtle berries and leaves extracts as potential active compounds. Leaves contain flavonoids, such as myricetin, quercetin, kaempferol, and catechins derivatives, and ellagitannins and phenolics acids, such as as ellagic and gallic acids [8-10]. Berries contain hydroxybenzoic acids, mostly gallic and ellagic acids, flavonols such as myricetin-3-O- 
galactoside, myricetin-3-O-rhamnoside, and myricetin-3-O-arabinoside, and flavanols such as (+)-catechin, (-)-epicatechin-3-O-gallate, (-)-epigallocatechin, and (-)-epigallocatechin-3-O-gallate [11]. Red-blue berries are rich in anthocyanins, especially delphinidin-3-O-glucoside, cyanidin-3-O-glucoside, petunidin-3-O-glucoside, peonidin 3-O-glucoside, malvidin 3-O-glucoside, cyanidin 3-O-arabinoside, delphinidin 3-O-arabinoside, petunidin 3-O-arabinoside, and malvidin-3-O-arabinoside [12,13]. The presence of these antioxidant compounds [14-16] makes consumption of myrtle a source of bioactive compounds, as well as other berries [17].

The polyphenolic compounds of plants generated benefits for human health [18], and in vitro phenolic compounds and flavonoids showed a higher antioxidant power than carotenoids and vitamins $\mathrm{C}$ and $\mathrm{E}$ [19]. Flavonoids play a protective role against diseases associated with oxidative stress, such as coronary and degenerative diseases, and against inflammation, ulcers, arthritis, and osteoporosis [20,21]. Recent research in myrtle [22] highlighted the positive effect of the polyphenols present in some extracts on fibroblasts of human cells subjected to oxidative stress. In plants, flavonoids synthesis occurs in all tissues and plays an important role in the interaction with the environment and/or other organisms [23,24]. Moreover, the phenolic profile of fruits is also a quality marker in the cultivar selection of myrtle and other small-fruit species [12,25-27].

As defined by [28], plant phenolics are secondary natural metabolites arising biogenetically both from the shikimate/phenylpropanoid pathway, which directly provides phenylpropanoids, and, alternatively, from the polyketide acetate/malonate pathway.

Most phenols compounds originate from the phenylalanine produced by the biosynthetic pathway of shikimic acid. The enzyme phenylalanine ammonia lyase (PAL) catalyzes condensation of a molecule of L-phenylalanine and four molecules of coenzyme-A with the formation of a trans-cinnamic acid and ammonium ion. The conversion of trans-cinnamic acid into flavonoids, such as anthocyanins, requires other reactions catalyzed by specific enzymes [29].

PAL belongs to the plant aromatic amino acid ammonia-lyase enzymes family and is a key enzyme in the regulation of carbon flow from primary to secondary metabolism [30]. PAL finds application in the industry, especially in the pharmaceutical and medical fields [31]. In several plants, the biosynthesis/accumulation of anthocyanins and other flavonoids correlated with PAL activity/expression, through the support of cinnamic acid [32,33]. In other studies [34,35], however, discrepancy between the dynamics of anthocyanins and PAL activity suggested that PAL is an essential enzyme for their biosynthesis but may not be a limiting factor in the regulation of accumulation mechanisms. PAL may be active in various parts of the plant and its expression/accumulation is associated with plant protection under environmental stress, such as a high concentration of sodium chloride $(\mathrm{NaCl})$ in soil [36] and exposure to ultraviolet radiation [37]. The PAL enzyme has an antioxidant function because it captures ROS (oxygen radical species) through the synthesis of phenolic compounds [38]. Sometimes, an increase in PAL activity may be a biochemical marker for the resistance of plants to environmental stress [39]. In the post-harvest of horticultural commodities, the PAL activity prepares defense against pathogens and physiological disorders. For example, during cold storage of 'Fortune' mandarins, the increase in PAL activity reduces the chilling symptoms [40]. In addition, in tomato fruits, the induction of PAL activity is related to limiting chilling injury damages [41].

In recent years, one of the main objectives of the breeding program has been to select cultivars more suitable for food products with human health benefits. In this sense, engineering works can modify the expression/activity of PAL to obtain a high production of phenolic compounds, as reviewed by [42].

The aim of this work was to study the activity of PAL in berry and leaves as related to the changes in the amounts of total polyphenols, anthocyanins, flavonoids, and tannins from flowering to berry maturation in two model cultivars of myrtle selected in Sardinia: One with pigmented berries and one with unpigmented berries. Previous studies on these biological models showed that genotypes with unpigmented fruits, in spite of the lack of anthocyanins accumulation, achieve a final level of total polyphenols both in leaves and in berries similar to those observed in genotypes with pigmented 
fruits $[1,8]$. Moreover, the antioxidant properties of leaves and fruit extracts of both genotypes are quite similar [14]. Consequently, the working hypothesis is that genotypes with unpigmented fruits may have the possibility to accumulate some useful kind of polyphenols alternative to anthocyanins, like elagitannins, which are in the interest of pharmacological industry. In order to demonstrate this hypothesis, it is necessary to provide a complete definition of the gene expression of the biosynthesis of the main polyphenol categories, and this research is just a preliminary step.

The practical objective of this complex research program is to understand the genetic mechanisms that determine the potential accumulation of different families of polyphenols and select genotype over-producers of useful compounds. This is in order to provide the myrtle industry of suitable cultivars for the biomass production with a predictable chemical composition and yield of selected compounds.

\section{Materials and Methods}

\subsection{Plant Material}

Plant materials, leaves, and berries, were sampled from plants of Myrtus communis previously selected from the spontaneous flora [2] and growing in the experimental field of the University of

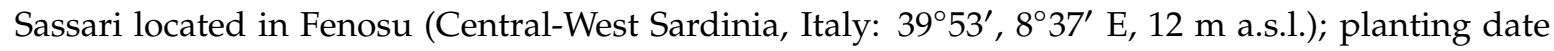
was in 1995. In particular, the research involved two cultivars, white ('Grazia') and pigmented berry ('Giovanna') originating by the same geographical area.

Harvests of leaves and berries of each cultivar were from full bloom until complete ripening of the berries. Samples were taken monthly for eight sample dates $(0,30,60,90,120,150,180$, and 210 days after flowering (DAF)). A plot of twenty growing plants for each cultivar was the unity for the random sampling. Samples were three for each sampling date, for a total of 24 leaf and 24 berry samples for each cultivar.

\subsection{Reagents}

Carlo Erba reagents S.r.l (Milan, Italy) purchased all reagents mentioned in this work, except for those purchased by Merck (Darmastadt, Germany): Catechin, $\beta$-Mercaptoethanol, and ammonium sulfate.

\subsection{Preparation of Extracts}

Tissue processing included: Grinding of a fruit pulp sample of $0.4 \mathrm{~g}$ (discarding seeds) or leaf tissue in liquid nitrogen with a pestle and mortar; sample transfer in a test tube; dilution in $10 \mathrm{~mL}$ of acidified ethanol ( $0.1 \%$ hydrochloric acid); and storing in the dark overnight at room temperature. After filtration, chemical analysis of the extracts occurred immediately or after storage at $-20^{\circ} \mathrm{C}$.

\subsection{Chemical Analysis}

Total phenolic content determination followed the Folin-Ciocalteu colorimetric method, by placing in $50 \mathrm{~mL}$ flasks $0.5 \mathrm{~mL}$ of diluted extract with $35 \mathrm{~mL}$ of deionized water, $2.5 \mathrm{~mL}$ of Folin-Ciocalteau reagent, and, after $3 \mathrm{~min}, 5 \mathrm{~mL}$ of sodium carbonate solution (20\% in water). Subsequent solution heating at $70{ }^{\circ} \mathrm{C}$ for $20 \mathrm{~min}$ and brought to volume $(50 \mathrm{~mL})$ with deionized water completed the sample preparation. Absorbance readings were at $\lambda=750 \mathrm{~nm}$ with a CARY 50 Scan UV-Vis VARIAN (Amsterdam, The Netherlands) spectrophotometer. Total phenols resulted in $\mathrm{mg}$ of gallic acid equivalents (GAE)/g of dry matter. Placing $1 \mathrm{~g}$ of sample in an oven at $105^{\circ} \mathrm{C}$ for $24 \mathrm{~h}$ determined the dry substance content.

Determination of anthocyanins content was as reported by [43]: Adding the ethanolic extract appropriately diluted it to a $\mathrm{pH} 1$ buffer solution (potassium chloride, $0.025 \mathrm{M}$ ). After $30 \mathrm{~min}$ of incubation, the absorbance reading at 520 and $700 \mathrm{~nm}$ against a blank, prepared with the same extract added of a $\mathrm{pH} 4.5$ buffer solution (sodium acetate, $0.4 \mathrm{M}$ ), allowed us to calculate results expressed in $\mathrm{mg}$ of cyanidin 3-glucoside equivalents/g of dry matter. 
Tannins determination followed the procedure reported by [44]: $4 \mathrm{~mL}$ of the diluted extract mixed with $2 \mathrm{~mL}$ of ethanol and $4 \mathrm{~mL}$ of the vanillin solution (1\% vanillin in $70 \%$ sulfuric acid), and reading absorbance at $500 \mathrm{~nm}$ after $30 \mathrm{~min}$, gave results expressed in $\mathrm{mg}$ of catechin (CE)/g of dry matter.

The method of aluminum nitrate colorimetry was the tool to measure total flavonoid content. The process included mixing $1 \mathrm{~mL}$ of the myrtle ethanolic extract with $0.3 \mathrm{~mL}$ of $5 \% \mathrm{NaNO}_{2}$ solution, the addition of $0.5 \mathrm{~mL}$ of a $10 \% \mathrm{AlCl}_{3}$ solution after $5 \mathrm{~min}$, and the addition of $0.5 \mathrm{~mL}$ of $1 \mathrm{M} \mathrm{NaOH}$ after standing for $6 \mathrm{~min}$. After a further $10 \mathrm{~min}$ at room temperature, the absorbance reading at $510 \mathrm{~nm}$ allowed results calculation in $\mathrm{mg}$ of catechin (CE)/g of dry matter.

\subsection{Extraction and Assays of Phenylalanine Ammonia-Lyase (PAL)}

Phenylalanine ammonia-lyase extraction was carried out according to [45] with some modifications. Acetone powder tissue was the first step for PAL activity determination. Sample preparation included the grounding of one gram of fresh tissue (leaves and berries) with a pestle and mortar using liquid nitrogen, addition of $10 \mathrm{~mL}$ of pre-cooled acetone, and mixing and placing at $-20^{\circ} \mathrm{C}$ for $15 \mathrm{~min}$. Filtering, washing twice with cold acetone, and drying at room temperature concluded the sample preparation. The PAL activity was measured mixing $25 \mathrm{mg}$ of acetone powder with $1.5 \mathrm{~mL}$ of $100 \mathrm{mM}$ sodium borate buffer ( $\mathrm{pH} 8.0$ ), containing $20 \mathrm{mM}$ of $\beta$-mercaptoethanol. A tissue lyser stirring treatment for $1 \mathrm{~min}$ followed the extract placement in $2 \mathrm{~mL}$ Eppendorf with two stainless steel balls. After centrifugation at $13,000 \mathrm{rpm}$, sample treatment continued with the partial supernatant purification by salting proteins with $60 \%$ ammonium sulfate, placing on ice for $30 \mathrm{~min}$, and centrifugation at 13,000 rpm for $30 \mathrm{~min}$. Subsequent supernatant discard, pellet recovery in $1.5 \mathrm{~mL}$ of $100 \mathrm{mM}$ sodium borate buffer (pH 8.0), and mixing and centrifugation for 2 min concluded the procedure with the final supernatant collection for the determination of PAL activity. The assay mixture contained $0.66 \mathrm{~mL}$ of enzyme solution and $0.2 \mathrm{~mL}$ of $0.1 \mathrm{M}$ l-phenylalanine, in a total volume of $2 \mathrm{~mL}$. The control, instead of l-phenylalanine, contained distilled water. Sample incubation was of $2 \mathrm{~h}$ at $40^{\circ} \mathrm{C}$ with three replications. The production of cinnamate for $120 \mathrm{~min}$ at $40{ }^{\circ} \mathrm{C}$ measured by the absorbance change at $270 \mathrm{~nm}$ determined the PAL activity.

\subsection{Data Analysis}

The MSTAT-C (Michigan State University, East Lansing, MI, USA) microcomputer statistical program was the data processor for ANOVA. Mean separation was performed by application of Duncan's multiple-range test at a $p \leq 0.01$ level of significance. Correlation analysis was applied using MSTAT-C software to establish the correlations between PAL activity and phenolic compounds.

\section{Results}

\subsection{Chemical Analysis}

\subsubsection{Total Polyphenols}

The polyphenols content of berries and leaves showed a similar trend in both cultivars. Both in the white and pigmented cultivars, the maximum polyphenol content in the berries was recorded during full flowering, with values of 208 and $130 \mathrm{mg} \mathrm{GAE} / \mathrm{g}$ DM (dry matter), respectively. In the last sampling dates, the polyphenol content decreased drastically until reaching the minimum values when the fruits were completely ripe: $37 \mathrm{and} 46 \mathrm{mg}$ in 'Giovanna' and 'Grazia' respectively. The white berry cultivar 'Grazia' showed statistically higher polyphenol content only during full flowering and 60 DAF (Figure 1).

In leaves, the polyphenol content of both cultivars was higher during full flowering, decreased slightly in the following stages and increased again near the full coloration of the fruit (150 DAF). 


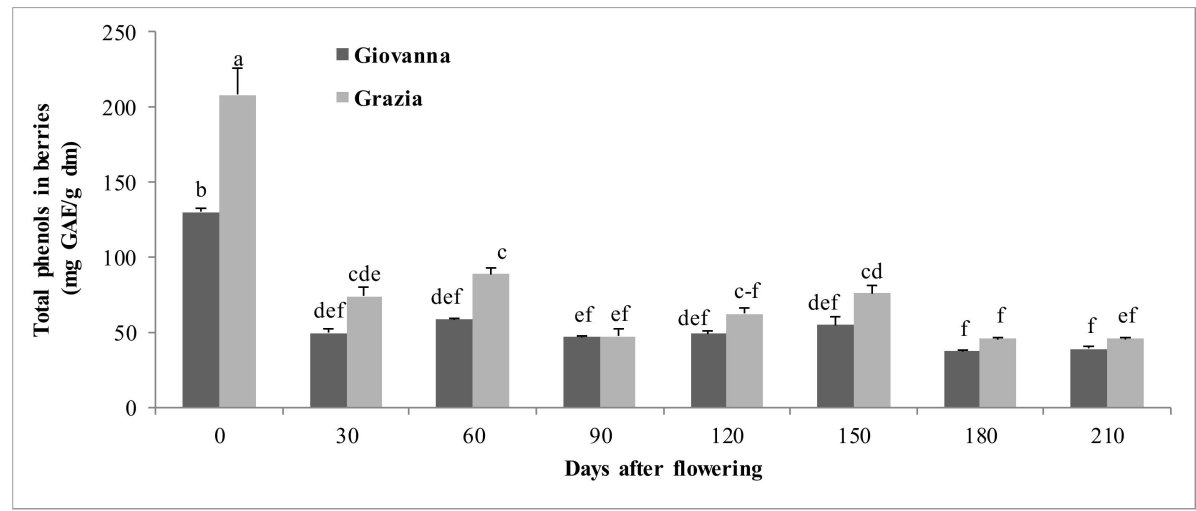

Figure 1. Evolution of polyphenol content in myrtle fruits in white ('Grazia') and pigmented cultivar ('Giovanna'). Data are the means of three replications, and the error bars indicate the standard error. Data labelled with the same letters are non-significantly different for $p \leq 0.01$.

However, the differences between the cultivars were irrelevant and were statistically different only after 30 DAF from full flowering, when leaves of the pigmented cultivar reached its maximum values (141.12 mg GAE /g/DM) (Figure 2).

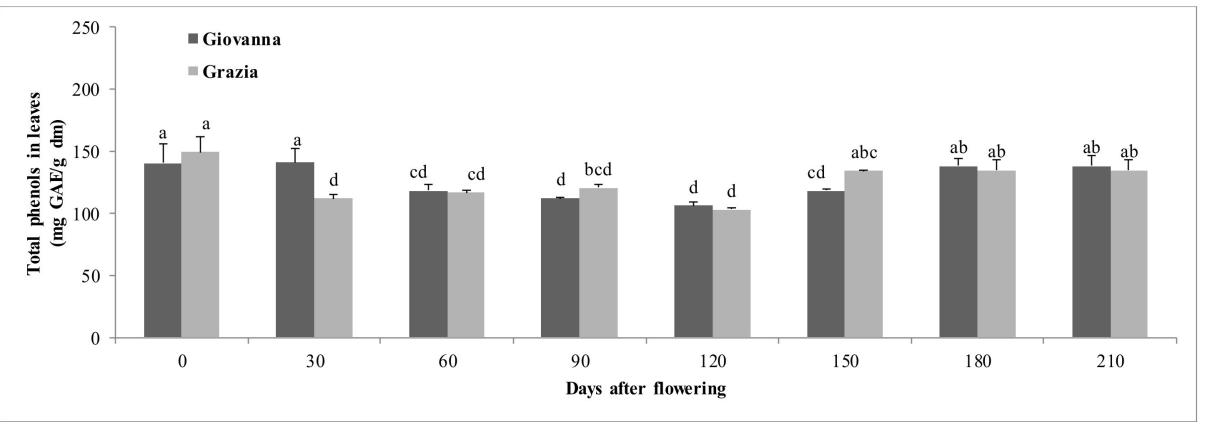

Figure 2. Evolution of polyphenol content in myrtle leaves in white ('Grazia') and pigmented cultivar ('Giovanna'). Data are the means of three replications, and the error bars indicate the standard error. Data labelled with the same letters are non-significantly different for $p \leq 0.01$.

\subsubsection{Anthocyanins}

The anthocyanin content in the fruits of the white cultivar and in the leaves of both cultivars was irrelevant. In pigmented cultivar ('Giovanna'), the anthocyanin content increased with the maturation from $3.5 \mathrm{mg}$ of cyanidin/g DM (150 DAF) to a maximum of $9.47 \mathrm{mg}$ (210 DAF) (Figure 3).

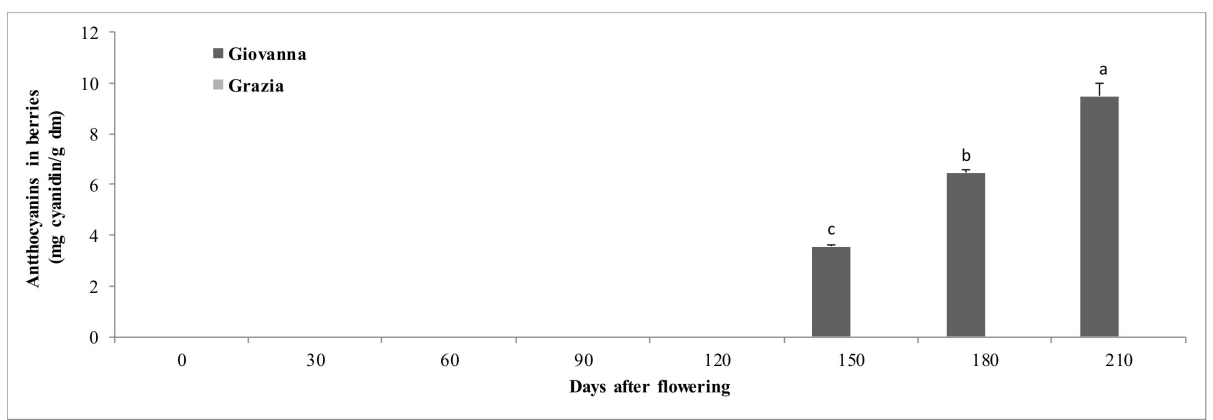

Figure 3. Evolution of anthocyanins in myrtle fruit in white ('Grazia') and pigmented cultivar ('Giovanna'). Data are the means of three replications, and the error bars indicate the standard error. Data labelled with the same letters are non-significantly different for $p \leq 0.01$. 


\subsubsection{Tannins}

The tannins content in the berries of the pigmented cultivar 'Giovanna' ranged from 0 to $1.49 \mathrm{mg} \mathrm{CE} / \mathrm{g} \mathrm{DM}$ (60 DAF). In the white cultivar berries 'Grazia' tannins ranged from 0 to $2.73 \mathrm{mg} \mathrm{CE} / \mathrm{g}$ DM (150 DAF). The differences between cultivars were statistically different only at 150 DAF (Figure 4).

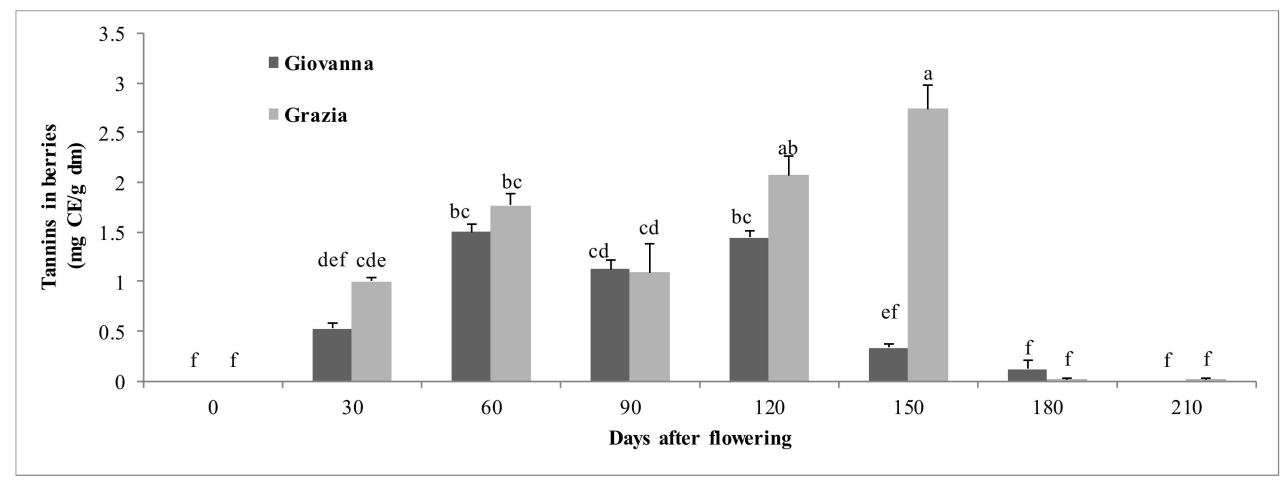

Figure 4. Evolution of tannins in myrtle fruit in white ('Grazia') and pigmented cultivar ('Giovanna'). Data are the means of three replications and the error bars indicate the standard error. Data labelled with the same letters are non-significantly different for $p \leq 0.01$.

The tannins content in the leaves in both cultivars was lower than that of the berries and varied between 0 and $0.27 \mathrm{mg} \mathrm{CE} / \mathrm{g} \mathrm{DM}(120 \mathrm{DAF})$. As for the berries, and for the leaves, the tannins content in the white cultivar ('Grazia') was higher than the pigmented one ('Giovanna'), especially at 120-150 DAF (Figure 5).

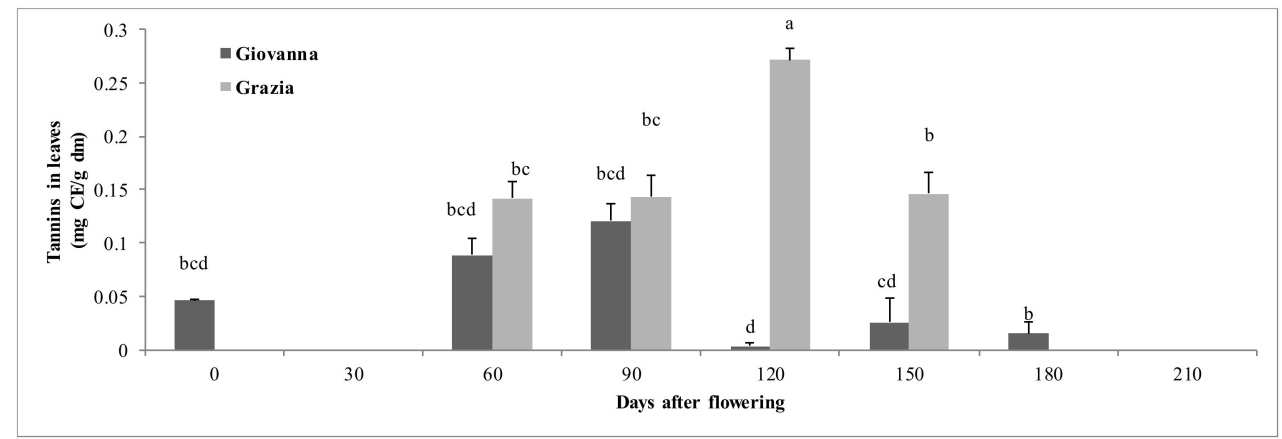

Figure 5. Evolution of tannins in leaves in white ('Grazia') and pigmented cultivar ('Giovanna'). Data are the means of three replications and the error bars indicate the standard error. Data labelled with the same letters are non-significantly different for $p \leq 0.01$.

\subsubsection{Flavonoids}

In pigmented cultivar 'Giovanna' the flavonoids content of berries ranged from a minimum of $0 \mathrm{mg}$ in full bloom to a maximum of $7.65 \mathrm{mg} \mathrm{CE} / \mathrm{g}$ DM a month later when the fruit was fully ripe. In white cultivar 'Grazia' the flavonoids content of berries ranged between 0 at full bloom to $5.1 \mathrm{mg} \mathrm{CE} / \mathrm{g}$ DM at $150 \mathrm{DAF}$ (Figure 6).

In the leaves of both cultivars, the flavonoids were detectable only after 90 and 120 days from full flowering, with values of 8 and $6.4 \mathrm{mg} \mathrm{CE} / \mathrm{g}$ DM in the pigmented cultivar and 9.8 and $8.9 \mathrm{mg} \mathrm{CE} / \mathrm{g}$ $\mathrm{DM}$ in the white cultivar (Figure 7). 


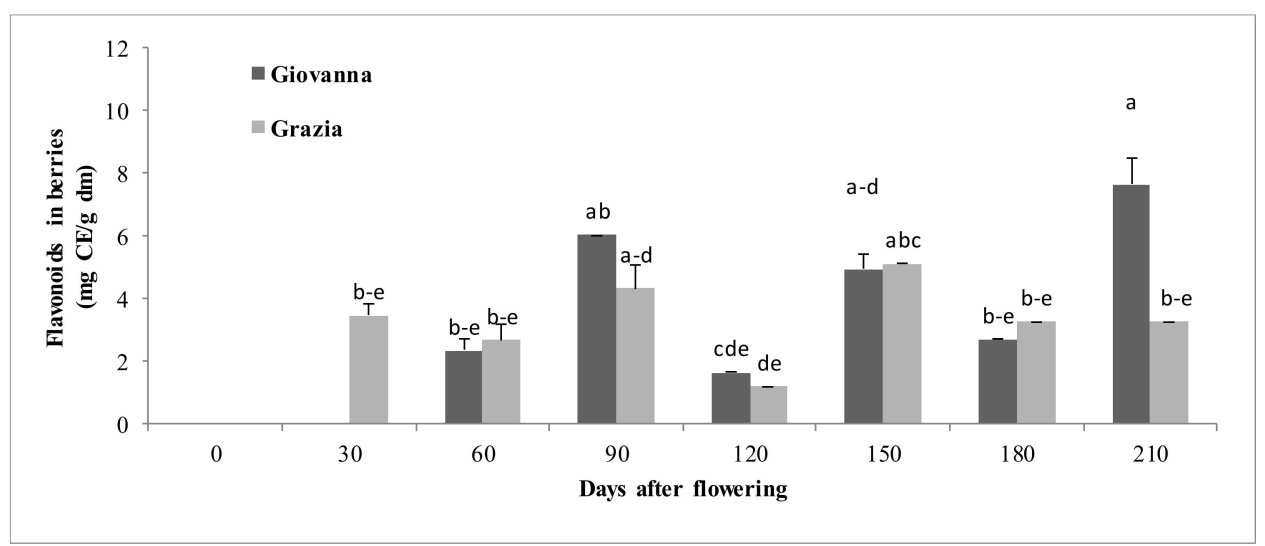

Figure 6. Evolution of flavonoids in myrtle fruit in white ('Grazia') and pigmented cultivar ('Giovanna'). Data are the means of three replications, and the error bars indicate the standard error. Data labelled with the same letters are non-significantly different for $p \leq 0.01$.

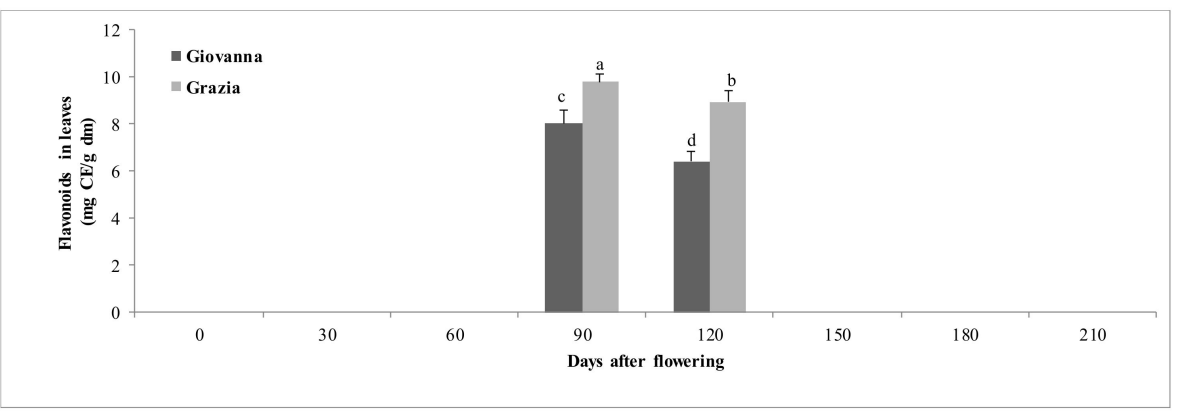

Figure 7. Evolution of flavonoids in leaves in white 'Grazia') and pigmented cultivar ('Giovanna'). Data are the means of three replications and the error bars indicate the standard error. Data labelled with the same letters are non-significantly different for $p \leq 0.01$.

\subsubsection{PAL Activity}

PAL activity, expressed as a variation in absorbance at $270 \mathrm{~nm}$, in the berries of the pigmented cultivar varied from a minimum of 0.004 at full flowering to a maximum of 0.25 after 150 DAF. In white cultivar, it ranged between 0.009 after $30 \mathrm{DAF}$ and 0.073 at full ripening (Figure 8).

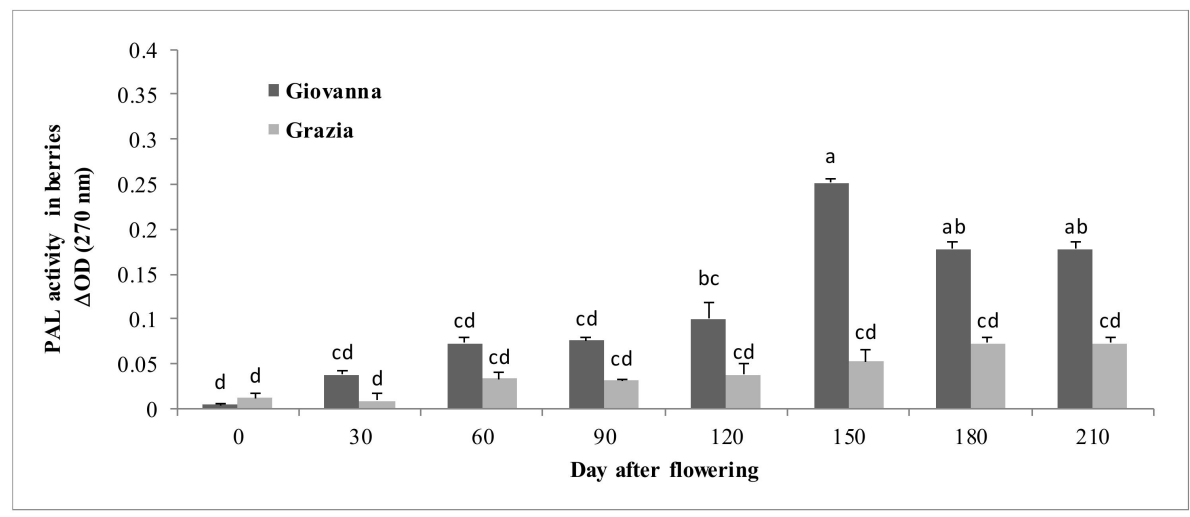

Figure 8. Evolution of phenylalanine ammonia lyase (PAL) activity in myrtle fruit in white ('Grazia') and pigmented cultivar ('Giovanna'). Data are the means of three replications, and the error bars indicate the standard error. Data labelled with the same letters are non-significantly different for $p \leq 0.01$.

In the leaves of the pigmented cultivar, the PAL activity varied from 0.05 at 150 DAF to 0.14 at full flowering, and from 0.04 at $150 \mathrm{DAF}$ to 0.08 at $120 \mathrm{DAF}$ in the white cultivar (Figure 9). 


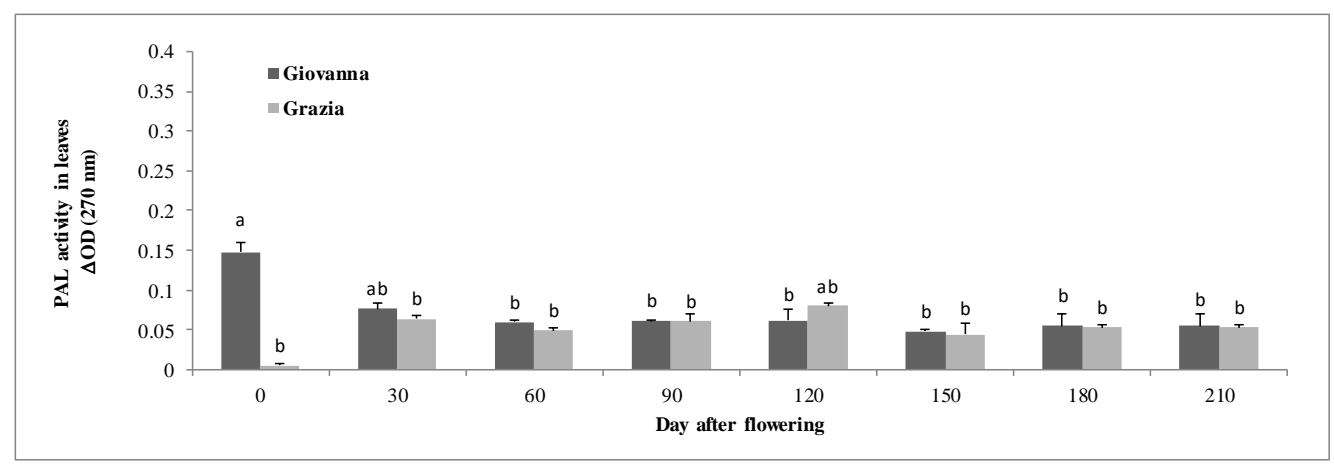

Figure 9. Evolution of PAL activity in leaves in white ('Grazia') and pigmented cultivar ('Giovanna'). Data are the means of three replications and the error bars indicate the standard error. Data labelled with the same letters are non-significantly different for $p \leq 0.01$.

\subsection{Correlation between Phenolic Compounds and PAL}

As shown in Table 1, the correlation analysis showed a positive correlation $(r=0.69)$ between the PAL activity in the berries and the content of anthocyanins and between the PAL activity and the flavonoids content in the berries $(r=0.44)$. Moreover, in the berries, a negative correlation was found between total phenols and PAL activity $(r=-0.44)$, and between flavonoids of the berries and total phenols $(r=-0.47)$. The flavonoids of the leaves negatively correlated with the phenols in the leaves and positively with the tannins of the leaves and berries. A positive correlation $(r=0.63)$ was present between the tannins of leaves and tannins of berries.

Table 1. Correlation coefficients (r) calculated between phenolic compounds and PAL activity ${ }^{\mathrm{z}}$.

\begin{tabular}{|c|c|c|c|c|c|c|c|c|}
\hline & $\begin{array}{c}\text { Total } \\
\text { Phenols } \\
\text { of Leaves }\end{array}$ & $\begin{array}{c}\text { Total } \\
\text { Phenols } \\
\text { of Berries }\end{array}$ & $\begin{array}{c}\text { Tannins } \\
\text { of Leaves }\end{array}$ & $\begin{array}{c}\text { Tannins } \\
\text { of Berries }\end{array}$ & $\begin{array}{c}\text { Anthocyanins } \\
\text { of Berries }\end{array}$ & $\begin{array}{l}\text { Flavonoids } \\
\text { of Leaves }\end{array}$ & $\begin{array}{c}\text { Flavonoids } \\
\text { of Berries }\end{array}$ & $\begin{array}{c}\text { PAL } \\
\text { of Leaves }\end{array}$ \\
\hline Total phenols of berries & $0.340 *$ & & & & & & & \\
\hline Tannins of berries & $-0.439 * * *$ & -0.115 & $0.633^{* * * *}$ & & & & & \\
\hline Anthocyanins of berries & 0.219 & -0.292 * & -0.267 & $-0.380^{* *}$ & & & & \\
\hline Flavonoids of leaves & $-0.509^{* * * *}$ & -0.238 & $0.532 * *$ & $0.369^{* *}$ & -0.251 & & & \\
\hline PAL of berries & -0.001 & $-0.445^{* * *}$ & -0.235 & -0.259 & $0.695^{* * * *}$ & -0.142 & $0.444^{* *}$ & -0.139 \\
\hline
\end{tabular}

\section{Discussion}

\subsection{Chemical Analysis}

The reduction in the polyphenol content with fruit ripening occurred in numerous species such as pomegranate [46], banana [47], some wild edible fruit [48], guava fruit [49], blueberry fruits [50], and olive drupe [51]. For the species Myrtus communis [44], a decrease in the total polyphenols of the fruits was characterized by ripening, showing a high intraspecific variability. This reduction could be due to the conversion of phenolic compounds or to the dilution of these when the fruits enlarge [52]. Furthermore, to explain the variations observed between cultivars in the different ripening stages, different storage mechanisms and the degradation rate of some phenols, compared to the synthesis rate of other groups of phenols [53], may be involved.

The polyphenol content in ripe berries was lower than that found by [54] $(70 \mathrm{mg} / \mathrm{g})$, while it was higher than that found by [44] (7 mg/g) and by [55] (14.7 mg/g). The polyphenol content in the leaves was similar to that found by [54] (119 mg/g), higher than that found by [56] (33.6 mg/g), and lower than those recorded by [57] (373 mg/g). According to [55], the leaves were notably richer in polyphenols than the berries. Other authors report a higher polyphenol content in berries than in flowers and 
leaves [58]. The white berry cultivar 'Grazia' showed a higher polyphenol content than the pigmented one 'Giovanna' this trend also occurs in other species $[8,49]$.

In some species, the reduction in the polyphenol content coincides with the increase in the anthocyanin content, as the polyphenols feed the biosynthesis of the flavilium ring during the formation of anthocyanins [58].

The anthocyanins constitute a major flavonoid group that is responsible for the cyanic colors of fruits, leaves, and flowers of angiosperms [59]. The berries of the white berry cultivar 'Grazia' were free of anthocyanins. In most cases, the model that best describes the accumulation of anthocyanins in the fruits that are rich in them is the sigmoidal model [60]. As shown in Figure 3, in pigmented cultivar 'Giovanna' the anthocyanin content in the berries increased with the maturation. The increase in anthocyanin with fruit ripening characterizes numerous species [61], including the species Myrtus communis, and is well-documented [35,44]. The concentration of anthocyanins in the berries is similar to that previously found by [44], on pigmented myrtle berries of Sardinian cultivars. However, compared to our data, the accumulation of anthocyanins began a month earlier.

In Myrtus communis species, tannins tend to decrease progressively with ripening, reaching a minimum between 120 and 210 days after flowering [44]. However, we have found that as the fruit ripens, the tannins content in the early stages increases and then decreases with ripening (corresponding to the increase in anthocyanins). In fact, we found a negative correlation (statistically significant) between the anthocyanin content in the berries and the tannins content $(r=-0.380)$. As for the berries, also for the leaves, the tannins content in the white cultivar 'Grazia' was higher than in the pigmented one 'Giovanna', especially at 120-150 DAF. The tannins content in the leaves and berries negatively correlated with the total polyphenol content in the leaves. Some authors $[55,56,58]$ suggest that the distribution of phenolic compounds is organ-dependent. In our research, we found that the tannins content in the leaves correlated positively with that of the tannins in the berries, but there was no flow of the compounds between the different organs of the plant.

According to [55,61], in Myrtus communis, such as for polyphenols, the flavonoids content was higher in the leaves than in the berries. Previous studies have shown that the highest quantity of flavonoids in myrtle was in branches ( $5 \mathrm{mg} / \mathrm{g}$ ), and in a negligible quantity in leaves $(3 \mathrm{mg} / \mathrm{g}$ ), berries $(1.21 \mathrm{mg} / \mathrm{g})$, and flowers [61]. In myrtle berries, flavonoids are concentrated mainly in the peel, while the content in seeds is insignificant. Usually with fruit ripening, the flavonoids content increases while polyphenols decrease [62]. However, in some species, this trend is different. In myrtle as well, we found the lowest flavonoids content at the last stages of ripening.

\subsection{PAL Activity and Phenolic Compounds during Fruit Development and Ripening}

The large classes of phenolic compounds derived from the phenylpropanoid pathway. PAL is a key regulatory enzyme for flavonoid biosynthesis during fruit ripening.

Myrtle plant is an important resource of bioactive compounds, such as phenolic compounds, but studies on the activity and expression of PAL on myrtle on the biosynthesis/accumulation of polyphenolic compounds are not available in the literature.

In berries, our results showed that the activity of the PAL was higher in the pigmented cultivar 'Giovanna' than in the white variety 'Grazia'. Although following the same trend, a low activity in the early stages of development and an increase in activity from color-break to full ripening occurred. A positive correlation $(p \leq 0.0001)$ exists between PAL activity and anthocyanin content in fruits of 'Giovanna' cultivar. In fruits that accumulate anthocyanins during ripening, PAL activity rises to a maximum when the fruits change color and anthocyanins start to accumulate [60]. The positive correlation found between PAL and anthocyanins content seems to indicate that the PAL enzyme regulates the pigmentation in myrtle berries. Other authors agree with this result. In grape, [33] found this correlation, comparing the relationship between PAL and anthocyanins accumulation in white, purple, and black cultivars during ripening. This study evidenced a first peak in the early stages of development of all varieties, in relation to the high level of phenols, and then a decrease from 
color-break. Subsequently, in the purple and black cultivars, a second peak of activity parallel to the accumulation of anthocyanins occurred. Always in grape, [63] observed the same positive correlation between PAL and anthocyanins accumulations. In red and green apple varieties, [64] found that the activity was high in the immature fruit and then decreased with ripening, but in the green variety, the second peak was lower than in the red one. This could be due to the lack of biosynthesis of anthocyanins or to the low levels of other flavonoids. In strawberry, also, two peaks occurred in the activity of the PAL during fruit development, the second coinciding with the accumulation of anthocyanins [35]. In the loquat fruit [65], maximum PAL activity was at the early stage of growth and 2 weeks before harvest. Furthermore, we found a positive correlation between PAL and berry flavonoids and a negative correlation between PAL and total phenols. The correlation between PAL activity and total flavonoids content was relatively low in berries $(r=0.44)$. This low correlation could be due to a time lag between enzyme activity and the accumulation of the synthesized compounds in the plant. It could also indicate that PAL is involved in other pathways in addition to flavonoids biosynthesis. Moreover, the negative correlation between PAL and berries phenolic compounds suggests that the enzyme activity mainly supported anthocyanins production, as shown previously. In addition, environmental and cultivation factors, and, in general, stress conditions to which the plants are prone strongly affected the PAL activity. For example, agronomic factors can also contribute to these differences [51], while water availability in fields [66] may show positive correlation with enzyme activity. PAL activity can vary among varieties of the same species, and among plants organs [35].

In addition, in several species (e.g., Arabidopsis thaliana), the PAL gene is encoded by a multigene family, and the different isoenzymes can be related to distinct points of phenylpropanoid pathways and can be tissue- or stimuli-dependent [67-69].

The positive correlation between total flavonoids and PAL activity might indicate the involvement of PAL in the formation of flavonoids, as reported by [39]. In olive drupe, a correlation between PAL enzymatic activity and total phenols amount occurred [51]. During fruit ripening, there was a reduction in the polyphenols content and a reduction in the PAL activity. Other authors [70] have recorded an increase in the PAL activity in conjunction with the fruit color change, during the last stages of ripening. In this case, however, any significant correlation between polyphenols and PAL activity was found. The same authors, studying the activity of the PAL in the leaves, found a correlation between the activity of the PAL and total phenols, which both increased with maturation.

In apple, [64] investigated the positive correlation between activity of PAL and flavonoids amount in the red variety during ripening. According to the authors, this low correlation originated by the fact that PAL in immature fruits is also involved in the biosynthesis of other phenolic compounds, like phenylpropanoids, which contribute to the seed hardening and lignification, but in the final stages of maturation, it is clearly involved in the biosynthesis of flavonoids and anthocyanins. Other authors in apples have found different results: A significant correlation between PAL and final anthocyanins content was absent, while a significant correlation between PAL and total flavonoids content was found. In apples, [71], instead, did not find any increase in activity in conjunction with the coloration of the fruit.

In strawberry, authors suggested [35] that the apparent lack of correlation between PAL and total phenols may be due to the accumulation of phenolic compounds that occurs before flowering, as well as the synthesis of insoluble compounds or depending on the analysis methodology. Differences in PAL levels in vitro and in vivo are also due to the presence of inhibitors such as $\mathrm{pH}$ [65]. Other research [72] indicates that the no correlation between PAL and polyphenolic compounds is due to phenylalanine substrate availability and not to the enzyme activity. The PAL activity in the leaves of 'Grazia' cultivar does not vary significantly during the fruit development and ripening, while in 'Giovanna' cultivar, the peak of activity was at 0 DAF.

In leaves, we did not find any correlation between PAL activity and total phenolic content or any of the phenolic compounds analyzed. In tea leaves, PAL activity decreased significantly with the maturity of leaf, and a close correlation with catechins accumulation was observed [73]. Contrarily, 
a positive correlation between PAL activity, total phenolics, and total flavonoids in leaves and a negative correlation between PAL activity and anthocyanin contents occurred in leaves of Pistachio cultivar [35]. We suppose that in the myrtle species, the activity of the PAL is organ-dependent and is mainly concentrated in the fruits. PAL is the first among the enzymes involved in the biosynthesis and accumulation of phenylpropanoids compounds, including flavonoids and tannins classes. Some other key enzymes involved in the flavonoids pathway are chalcone synthase (CHS), chalcone isomerase (CHI), flavanone 3-hydroxylase (F3H), leucoanthocyanidin dioxygenase (LDOX), and glucose flavonoid 3-O-glucosyl transferase (UFGT). The role of these enzymes in the accumulation of different phenolic compounds and in fruits pigmentation during fruit development was investigated in many fruit species, through the study of enzyme activity and gene expression levels [74,75]. As an integration of this study, insights on PAL gene expression level and studies on the expression/activity of other key enzymes will help to understand the genetic mechanisms in myrtle species.

\section{Conclusions}

Our results show that activity of the PAL enzyme in myrtle berries is associated with accumulation of flavonoids and anthocyanins, suggesting that PAL is a limiting-enzyme in flavonoids biosynthesis. In myrtle leaves, PAL activity seems not to be a limiting factor of phenolic compounds biosynthesis. This preliminary study on the enzymatic activity of PAL allows acquiring important knowledge on some phenolic compounds synthesis and accumulation in the myrtle plant. This is just a first step of our research program, which aimed at a complete definition of the gene expression of the PAL and of the other key enzymes in the polyphenols biosynthesis pathway. Other researches should support this information, and, in this direction, the use of the two genotypes with pigmented and unpigmented berries, as different metabolic models, is a useful tool to understand the critical points of the biosynthetic pathway of the main phenolic compounds. Moreover, another useful piece of information for this metabolomics study of myrtle could be the monitoring of PAL activity in relation to cultivation techniques and different environmental factors. This information will be useful in the breeding processes and allows including the myrtle plant among plant species used as a source of functional products.

Interest of the pharmaceutical and food industries on myrtle, as a functional product, is constantly growing. Therefore, given the high potential of myrtle biomass, our objective, through this preliminary study, is to provide further knowledge about this species from the metabolic point of view for genetic breeding. In particular, new information on the genetic mechanism of biosynthesis will allow the identification and selection of, among myrtle cultivars, previously propagated for cultivation, genotypes with high production of bioactive compounds, such as phenolic compounds, in the best form for processing industries. Moreover, this study will provide a basis for the study of the gene expression of flavonoids and anthocyanins biosynthesis in myrtle plant.

Author Contributions: The authors have contributed equally to this research. All authors have read and agreed to the published version of the manuscript.

Funding: The research was supported by the "Una tantum" found of the University of Sassari year 2019. The work of S.M. was partially supported by a grant of the Regione Autonoma della Sardegna P.O.R. program.

Conflicts of Interest: The authors declare no conflict of interest.

\section{References}

1. Mulas, M. The myrtle (Myrtus communis L.) case: From a wild shrub to a new fruit crop. Acta Hortic. 2012, 948, 235-242. [CrossRef]

2. Mulas, M.; Cani, M.R. Germplasm evaluation of spontaneous myrtle (Myrtus communis L.) for cultivar selection and crop development. J. Herbs Spices Med. Plants 1999, 6, 31-49. [CrossRef]

3. Alipour, G.; Dashti, S.; Hosseinzadeh, H. Review of pharmacological effects of Myrtus communis L. and its active constituents. Phytother. Res. 2014, 28, 1125-1136. [CrossRef] [PubMed] 
4. Amira, S.; Dade, M.; Schinella, G.; Ríos, J.L. Anti-inflammatory, anti-oxidant, and apoptotic activities of four plant species used in folk medicine in the Mediterranean basin. Pak. J. Pharm. Sci. 2012, 25, 65-72. [PubMed]

5. Cottiglia, F.; Casu, L.; Leonti, M.; Caboni, P.; Floris, C.; Busonera, B.; Farci, P.; Ouhtit, A.; Sanna, G. Cytotoxic Phloroglucinols from the Leaves of Myrtus communis. J. Nat. Prod. 2012, 75, 225-229. [CrossRef] [PubMed]

6. Babaee, N.; Mansourian, A.; Momen-Heravi, F.; Moghadamnia, A.A.; Momen-Beitollahi, J. The efficacy of a paste containing Myrtus communis (Myrtle) in the management of recurrent aphthous stomatitis: A randomized controlled trial. Clin. Oral Investig. 2010, 14, 65-70. [CrossRef]

7. Sumbul, S.; Ahmad, M.A.; Asif, M.; Saud, I.; Akhtar, M. Evaluation of Myrtus communis Linn. berries (common myrtle) in experimental ulcer models in rats. Hum. Exp. Toxicol. 2010, 29, 935-944. [CrossRef]

8. Mulas, M.; Melis, R.A. Influence of growing area, year, season, and cultivar on the composition of myrtle leaves and infusions. HortScience 2008, 43, 549-553. [CrossRef]

9. D’Urso, G.; Montoro, P.; Lai, C.; Piacente, S.; Sarais, G. LC-ESI/LTQOrbitrap/MS based metabolomics in analysis of Myrtus communis leaves from Sardinia (Italy). Ind. Crop. Prod. 2019, 128, 354-362. [CrossRef]

10. Romani, A.; Pinelli, P.; Mulinacci, N.; Vincieri, F.F.; Tattini, M. Identification and quantitation of polyphenols in leaves of Myrtus communis L. Chromatografia 1999, 49, 17-20. [CrossRef]

11. Barboni, T.; Cannac, M.; Massi, L.; Perez-Ramirez, Y.; Chiaramonti, N. Variability of polyphenol compounds in Myrtus Communis L. (Myrtaceae) berries from Corsica. Molecules 2010, 15, 7849-7860. [CrossRef] [PubMed]

12. Sarais, G.; D’Urso, G.; Lai, C.; Pirisi, F.M.; Pizza, C.; Montoro, P. Targeted and untargeted mass spectrometric approaches in discrimination between Myrtus communis cultivars from Sardinia region. Int. J. Mass Spectrom. 2016, 51, 704-715. [CrossRef] [PubMed]

13. Scorrano, S.; Lazzoi, M.R.; Mergola, L.; Di Bello, M.P.; Del Sole, R.; Vasapollo, G. Anthocyanins profile by Q-TOF LC/MS in Myrtus communis berries from Salento Area. Food Anal. Methods 2017, 10, 2404-2411. [CrossRef]

14. Sanna, D.; Delogu, G.; Mulas, M.; Schirra, M.; Fadda, A. Determination of free radical scavenging activity of plant extracts through DPPH assay: An EPR and UV-Vis study. Food Anal. Methods 2012, 5, 759-766. [CrossRef]

15. Sanna, D.; Mulas, M.; Molinu, M.G.; Fadda, A. Oxidative stability of plant hydroalcoholic extracts assessed by EPR spin trapping under forced ageing conditions: A myrtle case study. Food Chem. 2019, 271, 753-761. [CrossRef]

16. Babou, L.; Hadidi, L.; Grosso, C.; Zaidi, F.; Valentão, P.; Andrade, P.B.; Grosso, A.C. Study of phenolic composition and antioxidant activity of myrtle leaves and fruits as a function of maturation. Eur. Food Res. Technol. 2016, 242, 1447-1457. [CrossRef]

17. Škrovánková, S.; Sumczynski, D.; Mlcek, J.; Jurikova, T.; Sochor, J. Bioactive compounds and antioxidant activity in different types of berries. Int. J. Mol. Sci. 2015, 16, 24673-24706. [CrossRef]

18. Saxena, M.; Saxena, J.; Pradhan, A. Flavonoids and phenolic acids as antioxidants in plants and human health. Int. J. Pharm. Sci. Rev. Res. 2012, 16, 130-134.

19. Dai, J.; Mumper, R. Plant phenolics: Extraction, analysis and their antioxidant and anticancer properties. Molecules 2010, 15, 7313-7352. [CrossRef]

20. Yao, L.H.; Jiang, Y.; Shi, J.; Tomas-Barberan, F.A.; Datta, N.; Singanusong, R.; Chen, S.S. Flavonoids in food and their health benefits. Plant Foods Hum. Nutr. 2004, 59, 113-122. [CrossRef]

21. Patel, J.M. Review of potential health benefits of flavonoids. LURJ 2008, 3, 1-5.

22. Cruciani, S.; Santaniello, S.; Fadda, A.; Sale, L.; Sarais, G.; Sanna, D.; Mulas, M.; Ginesu, G.C.; Cossu, M.L.; Serra, P.A.; et al. Extracts from myrtle liqueur processing waste modulate stem cells pluripotency under stressing conditions. BioMed Res. Int. 2019, 2019, 5641034. [CrossRef] [PubMed]

23. Babenko, L.M.; Smirnov, O.E.; Romanenko, K.O.; Trunova, O.K.; Kosakivska, I.V. Phenolic compounds in plants: Biogenesis and functions. Ukr. Biochem. J. 2019, 91, 5-18. [CrossRef]

24. Mierziak, J.; Kostyn, K.; Kulma, A. Flavonoids as important molecules of plant interactions with the environment. Molecules 2014, 19, 16240-16265. [CrossRef] [PubMed]

25. González-De-Peredo, A.V.; Vázquez-Espinosa, M.; Espada-Bellido, E.; Palma, M.; Amores-Arrocha, A.; Palma, M.; Barbero, G.F.; Jiménez-Cantizano, A. Discrimination of myrtle ecotypes from different geographic areas according to their morphological characteristics and anthocyanins composition. Plants 2019, 8, 328. [CrossRef] [PubMed] 
26. Bertrams, J.; Kunz, N.; Müller, M.; Kammerer, D.; Stintzing, F.C. Phenolic compounds as marker compounds for botanical origin determination of German propolis samples based on TLC and TLC-MS. J. Appl. Bot. Food. Qual. 2013, 86, 143-153. [CrossRef]

27. Milivojević, J.; Rakonjac, V.; Akšić, M.M.F.; Pristov, J.B.; Maksimović, V. Classification and fingerprinting of different berries based on biochemical profiling and antioxidant capacity. Pesqui. Agropecu. Bras. 2013, 48, 1285-1294. [CrossRef]

28. Quideau, S.; Deffieux, D.; Douat-Casassus, C.; Pouysegu, L. Plant polyphenols: Chemical properties, biological activities, and synthesis. Angew. Chem. Int. Ed. 2011, 50, 586-621. [CrossRef]

29. Xie, R.; Zheng, L.; He, S.; Zheng, Y.; Yi, S.; Deng, L. Anthocyanin biosynthesis in fruit tree crops: Genes and their regulation. Afr. J. Biotechnol. 2011, 10, 19890-19897. [CrossRef]

30. Barros, J.; Dixon, R.A. Plant phenylalanine/tyrosine ammonia-lyases. Trends Plant Sci. 2020, 25, 66-79. [CrossRef]

31. Macdonald, M.J.; D'Cunha, G.B. A modern view of phenylalanine ammonia lyase. Biochem. Cell Biol. 2007, 85, 273-282. [CrossRef]

32. Singh, K.; Kumar, S.; Rani, A.; Gulati, A.; Ahuja, P.S. Phenylalanine ammonia-lyase (PAL) and cinnamate 4-hydroxylase (C4H) and catechins (flavan-3-ols) accumulation in tea. Funct. Integr. Genom. 2009, 9, 125-134. [CrossRef]

33. Kataoka, I.; Kubo, Y.; Sugiura, A.; Tomana, T. Changes in L-phenylalanine ammonia-lyase activity and anthocyanin synthesis during berry ripening of three grape cultivars. J. Jpn. Soc. Hortic. Sci. 1983, 52, $273-279$. [CrossRef]

34. Zhang, Z.; Sun, C.; Yao, Y.; Mao, Z.; Sun, G.; Dai, Z. Red anthocyanins contents and the relationships with phenylalanine ammonia lyase (PAL) activity, soluble sugar and chlorophyll contents in carmine radish (Raphanus sativus L.). Hortic. Sci. 2019, 46, 17-25. [CrossRef]

35. Cheng, G.W.; Breen, P.J. Activity of phenylalanine ammonia-lyase (PAL) and concentrations of anthocyanins and phenolics in developing strawberry fruit. J. Am. Soc. Hortic. Sci. 1991, 116, 865-869. [CrossRef]

36. Sirin, S.; Aslım, B. Determination of antioxidant capacity, phenolic acid composition and antiproliferative effect associated with phenylalanine ammonia lyase (PAL) activity in some plants naturally growing under salt stress. Med. Chem. Res. 2019, 28, 229-238. [CrossRef]

37. Ghasemi, S.; Kumleh, H.H.; Kordrostami, M. Changes in the expression of some genes involved in the biosynthesis of secondary metabolites in Cuminum cyminum L. under UV stress. Protoplasma 2019, 256, 279-290. [CrossRef] [PubMed]

38. Tian, X.; Lei, Y. Nitric oxide treatment alleviates drought stress in wheat seedlings. Biol. Plant 2006, 50, 775-778. [CrossRef]

39. Nadernejad, N.; Ahmadimoghadam, A.; Hosseinifard, J.; Pourseyedi, S. Phenylalanin ammonia lyase activity, total phenolic and flavonoid content in flowers, leaves, hulls, and kernels of three pistachio (Pistacia vera L.) cultivars. Am. Eurasian J. Agric. Environ. Sci. 2012, 12, 807-814.

40. Lafuente, M.T.; Zacarías, L.; Martínez-Téllez, M.A.; Sanchez-Ballesta, M.T.; Dupille, E. Phenylalanine ammonia-lyase as related to ethylene in the development of chilling symptoms during cold storage of citrus fruits. J. Agric. Food Chem. 2001, 49, 6020-6025. [CrossRef] [PubMed]

41. Aghdam, M.S.; Asghari, M.; Farmani, B.; Mohayeji, M.; Moradbeygi, H. Impact of postharvest brassinosteroids treatment on PAL activity in tomato fruit in response to chilling stress. Sci. Hortic. 2012, 144, 116-120. [CrossRef]

42. Tomás-Barberán, F.A.; Espín, J.C. Phenolic compounds and related enzymes as determinants of quality in fruits and vegetables. J. Sci. Food Agric. 2001, 81, 853-876. [CrossRef]

43. Lee, J.; Durst, R.W.; Wrolstad, R.E. Determination of total monomeric anthocyanin pigment content of fruit juices, beverages, natural colorants, and wines by the $\mathrm{pH}$ differential method: Collaborative study. J. AOAC Int. 2005, 88, 1269-1278. [CrossRef]

44. Fadda, A.; Mulas, M. Chemical profile changes during myrtle (Myrtus communis L.) fruit development and ripening. Sci. Hortic. 2010, 125, 477-485. [CrossRef]

45. Ballester, A.R.; Lafuente, M.T.; González-Candelas, L. Spatial study of antioxidant enzymes, peroxidase and phenylalanine ammonia-lyase in the citrus fruit-Penicillium digitatum interaction. Postharvest Biol. Technol. 2006, 39, 115-124. [CrossRef] 
46. Kulkarni, A.P.; Aradhya, S. Chemical changes and antioxidant activity in pomegranate arils during fruit development. Food Chem. 2005, 93, 319-324. [CrossRef]

47. Ibrahim, K.E.; Abu-Goukh, A.A.; Yusuf, K.S. Use of ethylene, acetylene and ethrel on banana fruit ripening. Univ. Khartoum J. Agric. Sci. 1994, 2, 73-92.

48. Belwal, T.; Pandey, A.; Bhatt, I.D.; Rawal, R.S.; Luo, Z. Trends of polyphenolics and anthocyanins accumulation along ripening stages of wild edible fruits of Indian Himalayan region. Sci. Rep. 2019, 9, 5894. [CrossRef] [PubMed]

49. Bashir, H.A.; Abu-Goukh, A.B.A. Compositional changes during guava fruit ripening. Food Chem. 2003, 80, 557-563. [CrossRef]

50. Castrejón, A.D.R.; Eichholz, I.; Rohn, S.; Kroh, L.W.; Huyskens-Keil, S. Phenolic profile and antioxidant activity of highbush blueberry (Vaccinium corymbosum L.) during fruit maturation and ripening. Food Chem. 2008, 109, 564-572. [CrossRef]

51. Morelló, J.R.; Romero, M.P.; Ramo, T.; Motilva, M.J.; Romero, M.P. Evaluation of 1-phenylalanine ammonia-lyase activity and phenolic profile in olive drupe (Olea europaea L.) from fruit setting period to harvesting time. Plant Sci. 2005, 168, 65-72. [CrossRef]

52. Lakshminarayana, S.; Mathew, A.G.; Parpia, H.A.B. Changes in polyphenols of sapota fruit (Achras zapota L.) during maturation. J. Sci. Food Agric. 1969, 20, 651-653. [CrossRef]

53. Vlaic, R.A.; Mureşan, V.; Muresan, A.E.; Muresan, C.C.; Păucean, A.; Mitre, V.; Chis, S.M.; Muste, S. The changes of polyphenols, flavonoids, anthocyanins and chlorophyll content in plum peels during growth Phases: From fructification to ripening. Not. Bot. Horti Agrobot. 2018, 46, 148-155. [CrossRef]

54. Kanoun, K.; Belyagoubi-Benhammou, N.; Ghembza, N.; Atik Bekkara, F. Comparative studies on antioxidant activities of extracts from the leaf, stem and berry of Myrtus communis L. Int. Res. Food. J. 2014, 21, 1957-1962.

55. Amensour, M.; Sendra, E.; Abrini, J.; Bouhdid, S.; Pérez-Alvarez, J.A.; Fernández-López, J. Total phenolic content and antioxidant activity of myrtle (Myrtus communis) extracts. Nat. Prod. Commun. 2009, 4, 819-824. [CrossRef]

56. Wannes, W.A.; Mhamdi, B.; Sriti, J.; Ben Jemia, M.; Ouchikh, O.; Hamdaoui, G.; Kchouk, M.E.; Marzouk, B. Antioxidant activities of the essential oils and methanol extracts from myrtle (Myrtus communis var. italica L.) leaf, stem and flower. Food Chem. Toxicol. 2010, 48, 1362-1370. [CrossRef]

57. Gardeli, C.; Vassiliki, P.; Athanasios, M.; Kibouris, T.; Komaitis, M. Essential oil composition of Pistacia lentiscus L. and Myrtus communis L.: Evaluation of antioxidant capacity of methanolic extracts. Food Chem. 2008, 107, 1120-1130. [CrossRef]

58. Snoussi, A.; Essaidi, I.; Koubaier, H.B.H.; Chaabouni, M.M.; Bouzouita, N. Chemical composition and antioxidant activity of essential oils and ethanol extracts of Myrtus communis L. organs (Berries, Leaves and Floral buds). J. Soc. Chim. Tunis. 2012, 14, 69-76.

59. Andersen, O.M.; Markham, K.R. (Eds.) The anthocyanins. In Flavonoids: Chemistry, Biochemistry and Applications; CRC Press: Boca Raton, FL, USA, 2006; pp. 471-473.

60. Macheix, J.J.; Fleuriet, A.; Billot, J. Fruit Phenolics; CRC Press: Boca Raton, FL, USA, 1990.

61. Wannes, W.A.; Marzouk, B. Differences between myrtle fruit parts (Myrtus communis var. italica) in phenolics and antioxidant contents. J. Food Biochem. 2013, 37, 1745-4514. [CrossRef]

62. Manach, C.; Scalbert, A.; Morand, C.; Rémésy, C.; Jiménez, L. Polyphenols: Food sources and bioavailability. Am. J. Clin. Nutr. 2004, 79, 727-747. [CrossRef]

63. Hiratsuka, S.; Onodera, H.; Kawai, Y.; Kubo, T.; Itoh, H.; Wada, R. Enzyme activity changes during anthocyanin synthesis in 'Olympia' grape berries. Sci. Hortic. 2001, 90, 255-264. [CrossRef]

64. Lister, C.E.; Lancaster, J.E.; Walker, J.R. Phenylalanine ammonia-lyase (PAL) activity and its relationship to anthocyanin and flavonoid levels in New Zealand-grown apple cultivars. J. Am. Soc. Hortic. Sci. 1996, 121, 281-285. [CrossRef]

65. Ding, C.K.; Chachin, K.; Ueda, Y.; Imahori, Y.; Wang, C.Y. Metabolism of phenolic compounds during loquat fruit development. J. Agric. Food Chem. 2001, 49, 2883-2888. [CrossRef] [PubMed]

66. Ravichandran, R.; Parthiban, R. Changes in enzyme activities (polyphenol oxidase and phenylalanine ammonia lyase) with type of tea leaf and during black tea manufacture and the effect of enzyme supplementation of dhool on black tea quality. Food Chem. 1998, 62, 277-281. [CrossRef]

67. Yu, X.Z.; Fan, W.J.; Lin, Y.J.; Zhang, F.F.; Gupta, D.K. Differential expression of the PAL gene family in rice seedlings exposed to chromium by microarray analysis. Ecotoxicology 2018, 27, 325-335. [CrossRef] 
68. Huang, J.; Gu, M.; Lai, Z.; Fan, B.; Shi, K.; Zhou, Y.H.; Yu, J.Q.; Chen, Z. Functional analysis of the arabidopsis pal gene family in plant growth, development, and response to environmental stress. Plant Physiol. 2010, 153, 1526-1538. [CrossRef]

69. Olsen, K.M.; Lea, U.S.; Slimestad, R.; Verheul, M.; Lillo, C. Differential expression of four Arabidopsis PAL genes; PAL1 and PAL2 have functional specialization in abiotic environmental-triggered flavonoid synthesis. J. Plant Physiol. 2008, 165, 1491-1499. [CrossRef]

70. Ortega García, F.; Blanco, S.; Peinado, M.Á.; Peragón, J. Phenylalanine ammonia-lyase and phenolic compounds in leaves and fruits of Olea europaea L. cv. Picual during ripening. J. Sci. Food Agric. 2009, 89, 398-406. [CrossRef]

71. Ju, Z.G.; Yuan, Y.B.; Liou, C.L.; Xin, S.H. Relationships among phenylalanine ammonia-Iyase activity, simple phenol concentrations and anthocyanin accumulation in apple. Sci. Hortic. 1995, 61, 215-226. [CrossRef]

72. Margna, U. Control at the level of substrate supply-An alternative in the regulation of phenylpropanoid accumulation in plant cells. Phytochemistry 1977, 16, 419-426. [CrossRef]

73. Samanta, T.; Kotamreddy, J.N.R.; Ghosh, B.C.; Mitra, A. Changes in targeted metabolites, enzyme activities and transcripts at different developmental stages of tea leaves: A study for understanding the biochemical basis of tea shoot plucking. Acta Physiol. Plant. 2017, 39, 11. [CrossRef]

74. Wei, H.; Chen, X.; Zong, X.; Shu, H.; Gao, D.; Liu, Q. Comparative transcriptome analysis of genes involved in anthocyanin biosynthesis in the red and yellow fruits of sweet cherry (Prunus avium L.). PLoS ONE 2015, 10, e0121164. [CrossRef] [PubMed]

75. He, J.J.; Liu, Y.X.; Pan, Q.H.; Cui, X.Y.; Duan, C.Q. Different anthocyanin profiles of the skin and the pulp of yan73 (Muscat Hamburg $\times$ Alicante Bouschet) grape berries. Molecules 2010, 15, 1141-1153. [CrossRef] [PubMed]

(C) 2020 by the authors. Licensee MDPI, Basel, Switzerland. This article is an open access article distributed under the terms and conditions of the Creative Commons Attribution (CC BY) license (http://creativecommons.org/licenses/by/4.0/). 